\title{
Development of Social Studies Learning Character- Based with Connected Model at the Faculty of Social Sciences, Universitas Negeri Medan
}

\author{
Rosnah Siregar ${ }^{1}$, Deny Setiawan ${ }^{2}$, Apriani Harahap $^{3}$ \\ \{rosnahsiregar2015@gmail.com ${ }^{1}$, denysetiawan1978@gmail.com, ${ }^{2,}$ aprianaiharahap@ unimed.ac.id ${ }^{3}$ \} \\ ${ }^{1,2}$ Department of Citizenship Education Faculty of Social Science, Universitas Negeri Medan, \\ Indonesia \\ ${ }^{3}$ Department of History Education, Faculty of Social Science, Universitas Negeri Medan, Indonesia
}

\begin{abstract}
This development research aims to produce character-based social studies textbooks with connected models in the Faculty of Social Sciences, Medan State University. Specific targets to be achieved are the production of character-based social studies textbooks with connected models to improve the quality of social studies education as faculty courses (Teaching Courses SELF FIS UNIMED). The research method used by the R\&D method follows the Borg \& Gall procedure. The research subjects involve (1) lecturer supporting the Unimed FIS Identity Course; (2) students as subjects for limited group trials; and (3) four experts for the validation of teaching materials that have social studies expert criteria, plus Indonesian language experts and instructional material design experts. The instrument used was the expert validation questionnaire which was analyzed using the Average Score Percentage (PRS).
\end{abstract}

Keywords: Social studies learning, characters, connected models.

\section{Introduction}

The cultivation of character is very necessary because currently, the Indonesian Nation is experiencing a crisis of character in the nation's children. Character as a person's personality is formed from the internalization of various virtues that are believed and used as a basis for perspective, thinking, acting and acting. These virtues are in the form of several moral values, and norms, such as honesty, dare to act, can be trusted, respect for others, discipline, independent, hard work, creative [1].

The importance of character building in a tertiary institution must be supported by an innovative learning process. One of the lessons that can be associated with the character is social studies learning because social studies learning is directly related to social life. The character-based social studies learning system does not only emphasize knowledge insight but also foster attitudes and skills. Therefore, social studies learning should be designed comprehensively involving all three aspects, while integrating material content from allied social sciences in an integrated manner. Such social studies learning design is intended so that students have concern for the phenomenon of community life, critical-analytical, and have the competence to be able to solve social problems that exist around their environment.

However, from several studies and evaluations of social studies learning, social studies learning at both the school and university level tends to be theoretical and seems unrelated to 
the environment in which students are. Whereas the main function of the aim of IPS education is to prepare students (the next generation) with the abilities and expertise needed to have the readiness to enter the community (environment). Intelligent humans can only be produced through quality education, in the sense of education that not only develops elements of knowledge but also how to utilize and implement that knowledge for the community.

The facts above, illustrating the problem of social studies learning both at the level of schooling (SMP) and in tertiary institutions (LPTK) is not only related to the absence of a relationship between theory and practice but also other problems arise. According to [2]"the problem that arises in the IPS learning in junior high schools is that it is still implemented separately, the level of achievement of competency standards and basic competencies is carried out in accordance with the field of study of each social science without any integration in it so that it can hinder the achievement of objectives". Another problem according to [3] is "Social studies learning that should be given integrated in practice is still delivered separately because teachers refer to their educational qualifications so that it has difficulty integrating Social Studies learning". Even some social studies teachers in the same school, generally have different backgrounds or qualifications. Some teachers have qualifications from Geography, History, Economics, and Sociology. In other words, in general teachers in junior high schools do not have an integrated social education background. This condition is not much different from the implementation of social studies learning at the tertiary level (LPTK), as well as at FIS Unimed [4]. The implementation of social studies learning which tends to run separately between geography, economics, history, and sociology causes social studies learning to be less meaningful and not optimal in achieving its learning goals. This condition has an impact on the lack of competence of students, especially in training for critical-analytical thinking, caring attitude, and skilled in solving social problems.

Based on the above problems, in this study, it is proposed that social studies learning be carried out in an integrated manner by applying the connected model. Social studies learning with connected models are social studies learning planned and applied to connect one concept with other concepts, one topic with another topic, one skill with another skill, tasks performed in one day with tasks performed the next day, even ideas are learned in one semester with ideas learned in the next semester.

Character-based social studies learning with connected models helps lecturers who have different qualifications to have the same paradigm in applying social studies learning in an integrated manner and is also expected to help students to improve their understanding of social science comprehensively, and can foster their character as expected.

\section{Literature review}

Social Sciences (IPS) is an integration of various branches of social sciences such as sociology, history, geography, economics, politics, law, and culture. Social Sciences are formulated based on reality and social phenomena that embody an interdisciplinary approach from aspects and branches of social sciences (sociology, history, geography, economics, politics, law, and culture). Social studies or social studies are part of the school curriculum derived from the contents of the material branches of the social sciences: sociology, history, geography, economics, politics, anthropology, philosophy, and social psychology. Geography, history, and anthropology are disciplines that have high integration. Learning geography provides unanimity of insight regarding territories, while history provides insights regarding events from various periods. The integration of social sciences in social studies learning can be shown in the following figure. 


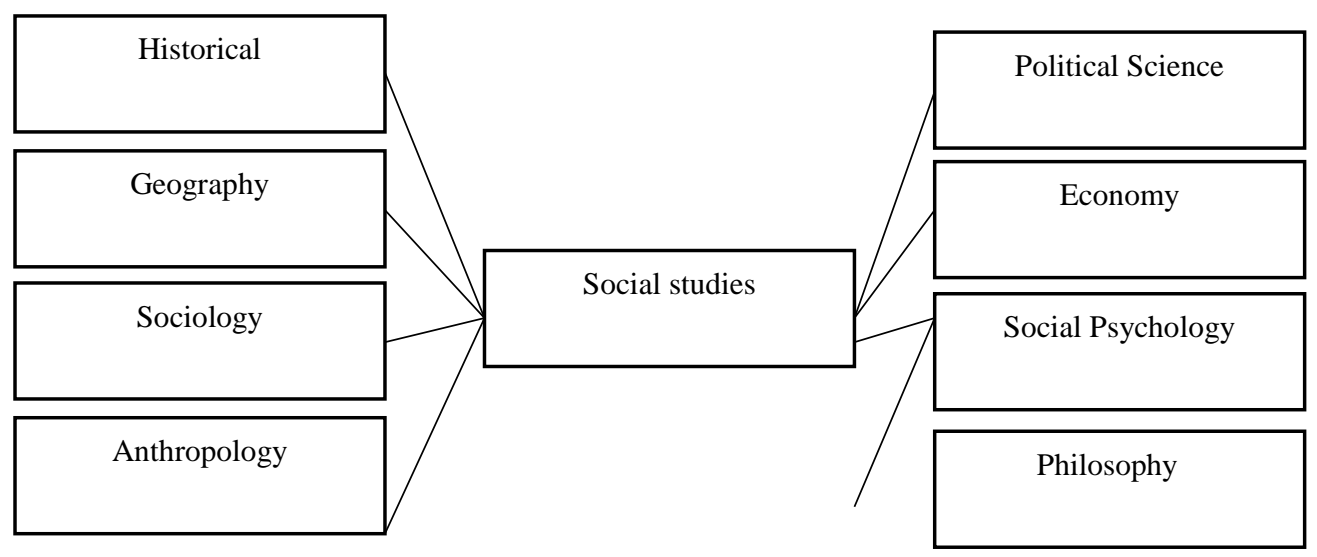

Fig. 1. Integration of the Social Sciences Branch

(Source: Reference [5])

Social studies materials are arranged in topics that contain concepts and generalizations that must be presented in accordance with the formulation of the meaning of social studies, concepts and generalizations from various branches of social science, such as: history, geography, sociology, anthropology, political science, economics, social psychology, and philosophy [5]. The National Council for Social Studies [6] defines Social Sciences as "the integrated study of social sciences and humanities to promote civic competence". Social Sciences is an integrated study of social sciences and humanities to promote social competence. In a systematic coordinated social science school program consisting of various disciplines, such as anthropology, archeology, economics, geography, history, law, philosophy, political science, psychology, religion, and sociology, as well as appropriate content from humanities, mathematics, and natural sciences. In essence, Social Sciences is concerned with the development and condition of society with all its problems. Therefore, it requires multidisciplinary science that is packaged in an integrated manner to master social studies learning.

Integrated IPS learning model [5] presents 10 (ten) groups of integrated learning models, namely: (1) Fragmented model, is a traditional learning model that separates disciplines from one another; (2) Connected model, is a learning model that focuses on the formation of a firm in connecting in a subject, the connection of a topic with a topic, a concept, between the task skills that are related in one day to the task done with the following days, ideas learning in one semester with ideas to be studied in the next semester in one field of study; (3) Nested model, which is a complex design design by getting certain extracts from the subjects handled; (4) Sequenced models apply the concept that a teaching material from a subject can be learned from another subject or vice versa; (5) The shared model, is to parcel the content of subjects across disciplines, allowing for new logical connections. If this benefits the student, the teacher will also benefit; (6) Webbed model, in its application the teacher's view is analogous to looking through a telescope, so that what appears to be a complete picture where all the relationships between subjects and their activities can be seen; (7) Threaded model, an approach to learning by using thinking skills, social skills, study skills, organizing clear learning, multi-intelligence technology from various subjects; (8) Integrated Model, 
combining four main types of scientific disciplines. Where each instructor establishes priorities of his scientific discipline; (9) Immersed Model, is one of the integrated learning models whose integration takes place within students; and (10) Networked models, networked teaching and planning have the aim so that students can filter all lessons through expert glasses and make internal connections that lead to external networks of experts in related fields.

Understanding the integrated learning Fogarty Connected Model [7] is a model of interdisciplinary integration of studies. This model integrates a concept, skill or ability that is developed in a subject or sub-topic that is related to the concept, skill or ability at the subject or other sub-subjects in one field of study. The connected model [8] is an integrated learning model that deliberately strives to connect one concept with another concept, one topic with another topic, one skill with another skill, tasks carried out in one day with the next day, even ideas are learned in one semester with the next semester in one field of study. Furthermore, the [8] explains three stages are passed in each integrated learning model connected, namely: (1) preparation phase, (2) implementation phase, (3) culmination stage, as presented in the following table:

Table 1. Connected Model Stages

\begin{tabular}{ccc}
\hline Planning & Implementation & Culmination \\
\hline $\begin{array}{c}\text { Concept maps of one field of study } \\
\text { Related concepts }\end{array}$ & $\begin{array}{c}\text { Execution of tasks } \\
\text { Analysis of the results of the } \\
\text { implementation of the task } \\
\text { Preparation of reports }\end{array}$ & $\begin{array}{c}\text { Presentation of report } \\
\text { Evaluation }\end{array}$ \\
\hline
\end{tabular}

Connected model is a learning model that focuses on establishing a firm relationship between a subject, the connection of one topic to the topic, one concept, between skills, tasks related in one day to the tasks done with the following days, ideas learned in one semester with ideas to be studied in next semester in one field of study. This connected model plays a role in overcoming students' difficulties when they find as if there are contradictions between concepts in other subjects on the same topic or at least relevant, this model also provides opportunities for students to deepen, review reconceptualizations, edit and assimilating ideas gradually and even at some stage can transfer.

The connected model is useful as a first step towards integrated learning. This is supported by the ability and skills of educators in finding connections in their fields of study. Achievement of the Social Sciences Basic Dasarmata Competency is still carried out following their respective fields of study (sociology, history, geography, economics) without any integration in it. This, of course, hinders the achievement of social studies objectives which are formulated based on reality and social phenomena that embody an interdisciplinary approach from the aspects and branches of social science (sociology, history, geography, economics, politics, law, culture). This is due to among others: (1) the IPS curriculum itself does not describe an integrated whole, but is still fragmented among the fields of social sciences; (2) the background of educators who have disciplines such as biography, history, economics, and sociology, anthropology is still very difficult to conduct learning that integrates interdisciplinary science.

The implementation of social studies learning in tertiary institutions (LPTK) which has implemented the KKNI-based curriculum, is not much different from the principles of the application of social studies learning as in the 2013 curriculum. Social studies material is not 
presented separately. However, the material is presented in an integrated manner using geography material as a study platform with the purpose of its location being to emphasize the importance of "space" connectivity in strengthening the Unitary Republic of Indonesia. History by emphasizing the connectivity of "time", so students can be trained to think chronologically, prospectively and anticipatively. Whereas Sociology/Anthropology and Economics emphasize the connectivity of "values/norms" so that students can be consistent with the rules that have been mutually agreed upon [9]. IPS learning is essentially an educational program that integrates social sciences for educational purposes. In its implementation, this educational program can be used as a systemic vehicle for character formation, through an integrated effort to integrate allied social sciences as presented in the following figure:

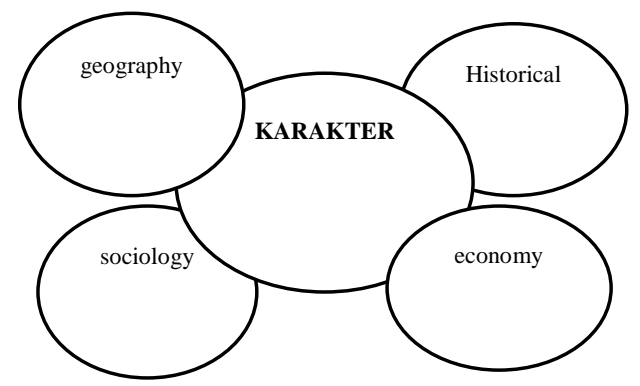

Fig.2. Model diagram connected [10]

\section{Research methods}

This research was conducted at the Faculty of Social Sciences (FIS), Medan State University, located at Jalan William Iskandar Pasar V Medan Estate. The time of the study was carried out from June-December 2019. Research subjects include: (1) lecturers of social studies as faculties/Unimed FIS Identity courses; (2) students as a limited trial group; (2) 6 validation experts consisting of: 4 IPS experts (Sociologists, History experts, Geographers and Economics experts), 1 textbook design expert, and 1 Indonesian Language expert. Borg \& Gallin [11]explained that the $R \& D$ method is a research that is intentionally and systematically directed to find findings, formulate, develop, produce, test the effectiveness of certain products that are superior, new, effective, efficient, productive and meaningful. In this study, the implementation of the R\&D method research follows the procedure developed by [12]:
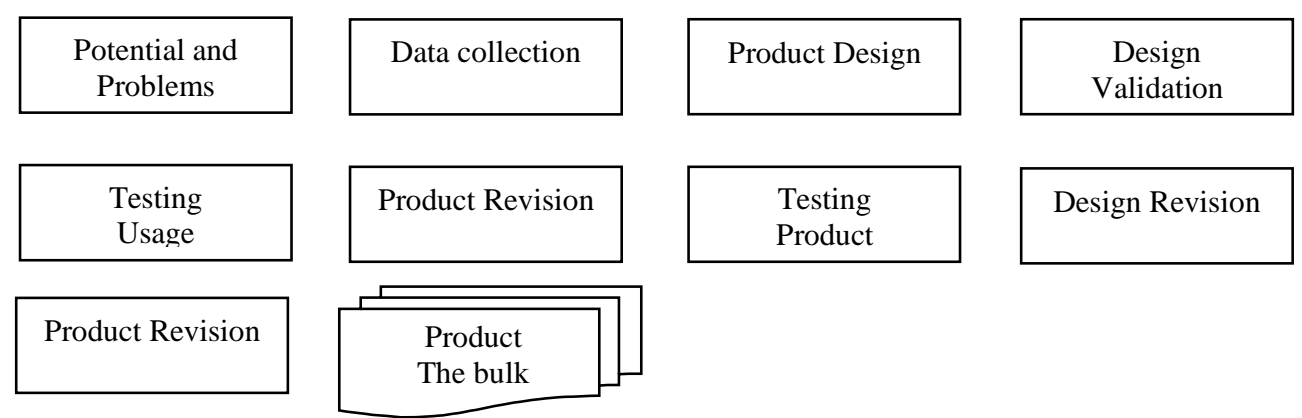

Design Revision 
Fig. 3. Steps in Research and Development [12]

The development procedures adopted to produce products in the form of IPS textbooks based on connected models are carried out in 4 stages, namely: (1) conducting preliminary research, (2) making textbook designs, (3) reviewing and testing textbooks in the context of formative evaluation and product revisions, and (4) Test product effectiveness.

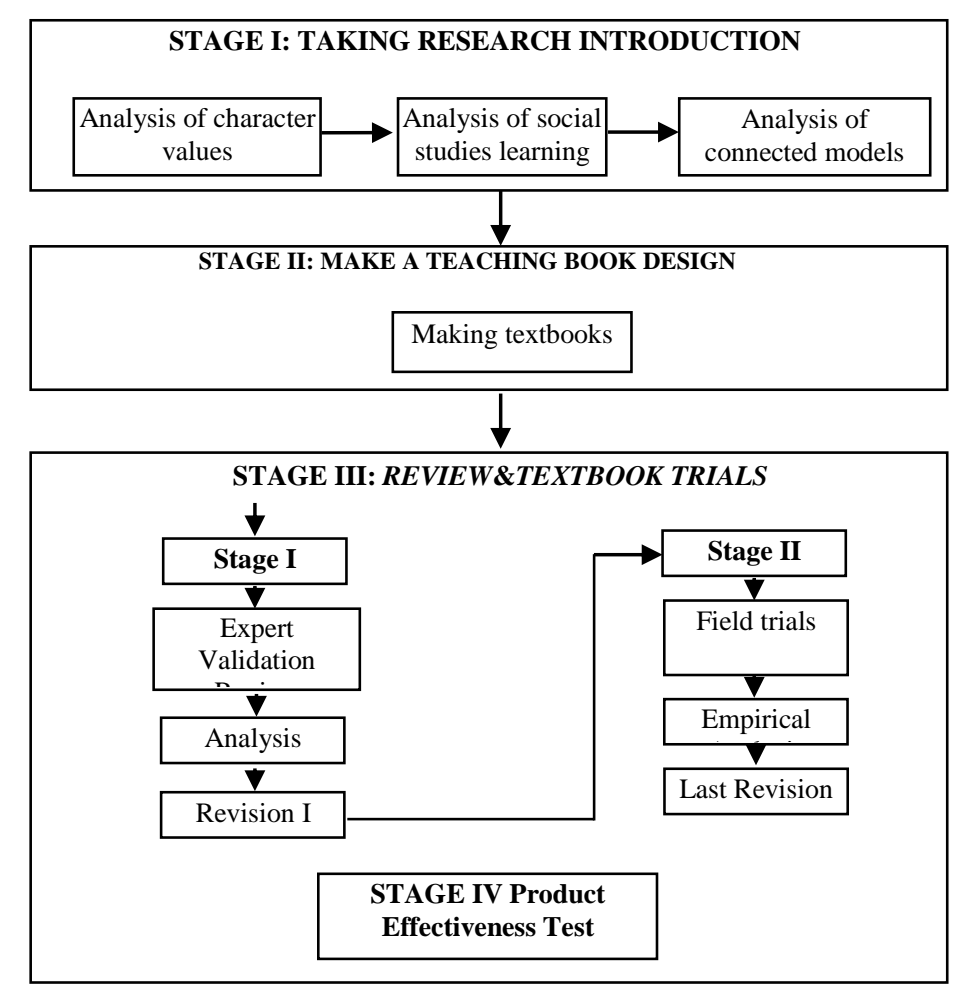

Fig. 4. Interactive Learning Media Development Procedure Chart, a blend of the Borg \& Gall and Dick \& Carey models

The instruments used in this study were: expert validation questionnaire. The expert validation questionnaire used a Likert scale that was modified by the researcher on a scale of 4. The evaluation criteria were classified at four levels with the following ratings: (1) Not good, (2) Good enough, (3) Good, (4) Very good, [13]. While the textbook questionnaire uses the Guttman scale which is a measurement scale with firm answers, namely yes-no, rightwrong, ever-never, positive-negative; [12]. The expert validation questionnaire is presented in Table 2 .

Table 2. Expert Validation Questionnaire Grid

\begin{tabular}{lll}
\hline No & Component & Sub-component \\
\hline
\end{tabular}




\begin{tabular}{ccl}
\hline I Content eligibility & a. The suitability of the description of the material with learning \\
& b. Material accuracy \\
& c. Material updates \\
& d. Encourage curiosity \\
II $\quad$ Feasibility of & a. Presentation technique \\
presentation & b. Supporting learning \\
& c. Coherence and chaos of thought flow \\
III Language Feasibility & a. Accurate \\
& b. Communicative \\
IV $\quad$ c. Suitability \\
& a. The continued story between chapters \\
& b. Contextual \\
& c. A concise and interesting story
\end{tabular}

This data analysis is used to validate character-based social studies learning with a connected model in the Faculty of Social Sciences, Medan State University, which was developed in the form of textbooks. To analyze the results of assessments given by experts on the quality and feasibility of the product will use the formula of Percentage of Average Score (PRS), as follows :

$$
\mathrm{PRS}=[13]
$$

With criteria:

$\begin{array}{ll}90 \% & \leq \text { PRS } \leq 100 \%=\text { Very Good } \\ 80 \% & \leq \text { PRS } \leq 90 \%=\text { Good } \\ 70 \% \leq \text { PRS } \leq 80 \%=\text { Enough }(\mathrm{C}) & \\ 60 \% & \leq \quad \text { PRS } \leq 70 \%=\text { less } \\ 0 \% & \leq \quad \text { PRS } \leq 60 \%=\text { very less }\end{array}$

\section{Results and discussion}

The research was arranged based on the development procedures adopted to produce a product in the form of a social science-based textbook with a connected model through the following 4 stages, namely: (1) conducting preliminary research, (2) creating a textbook design, (3) reviewing and testing textbooks in the context of formative evaluation and product revision, and (4) product effectiveness test.

Based on interviews with lecturers of faculties, social studies courses as a self-identity course at FIS Unimed, comprehensive learning outcomes have been compiled covering dimensions: knowledge, skills, and attitudes. However, the results of observations revealed that social studies learning should be implemented in an integrated manner, including the concept of space (living space) that exists in geography, the concept of time (time) that exists in history, and the concept of values (values) that exist in economics and sociology, still tend to be delivered separately. Therefore, it is necessary to develop integrated social studies learning by applying the connected model.

Development of IPS learning with connected models, designed to develop students' knowledge by linking concepts in geography, history, economics, and sociology as a theoretical provision to solve social problems skillfully. This learning design is built so that 
social studies education can contribute to the formation of students' character. This thinking is the reason in this research to develop social studies learning at FIS Unimed, with the final product being character-based social studies textbooks with connected models. Product design is done by developing a formulation of learning outcomes or character-based social studies learning outcomes under national standard qualifications. Learning outcomes of social studies learning are presented in the following table:

Table 3. Learning Outcomes Social Studies Learning

\begin{tabular}{|c|c|}
\hline Material & Learning Outcomes \\
\hline $\begin{array}{c}\text { Character-based } \\
\text { Geography Material }\end{array}$ & $\begin{array}{l}\text { Students can show attitude: caring, self-discipline, responsibility, honesty, } \\
\text { and citizenship while studying geography material which includes the } \\
\text { concepts of (1) definition, understanding and basic concept of geography, } \\
\text { (2) the relationship of location with physical and social conditions, (3) } \\
\text { effect of location on human activity, (4) spread patterns and spatial } \\
\text { interactions between villages/cities, (5) country and country location, and } \\
\text { (6) understand the region and the regional approach }\end{array}$ \\
\hline Historical Material & $\begin{array}{l}\text { Students can show attitude: caring, self-discipline, responsibility, honesty, } \\
\text { and citizenship while studying historical material which includes the } \\
\text { concepts of (1) the pre-literate period and the development of Hindu- } \\
\text { Buddhism in Indonesia, (2) the development of Islam in Indonesia, (3) } \\
\text { colonialism / imperialism towards socio-economic life, (4) the process of } \\
\text { forming national awareness and Indonesian identity, (5) Japanese } \\
\text { occupation of Indonesia, (6) recognition of Sovereignty and the Unitary } \\
\text { Republic of Indonesia, and (7) the New Order and reformation period }\end{array}$ \\
\hline $\begin{array}{l}\text { Economic material } \\
\text { Character-based }\end{array}$ & $\begin{array}{l}\text { Students can show attitude: caring, self-discipline, responsibility, honesty, } \\
\text { and citizenship while studying economic material which includes the } \\
\text { concepts of (1) the effect of location superiority on the economy, (2) } \\
\text { money and financial institutions, (3) bank financial institutions, (4) non- } \\
\text { bank financial institutions, and (5) cooperation between countries- } \\
\text { economic cooperation }\end{array}$ \\
\hline $\begin{array}{l}\text { Character-based } \\
\text { Sociology material }\end{array}$ & $\begin{array}{l}\text { Students can show attitude: caring, self-discipline, responsibility, honesty, } \\
\text { and citizenship while studying sociology material which includes the } \\
\text { concepts of (1) social interaction, (2) social change, (3) social mobility, (4) } \\
\text { social groups, social organizations, (5) socialization, and (6) agent of } \\
\text { socialization }\end{array}$ \\
\hline
\end{tabular}

The validation of social studies textbooks was carried out by a team of validators consisting of geography, history material experts, sociology material experts, economics material experts, Indonesian language material experts, and textbook design experts. Assessments provided by expert validators are analyzed by testing the validity and feasibility of the product. While the means of improvement from the expert validator is used as a reference or revision of the product being developed. The expert validator's evaluation of the IPS textbook is presented in the following table:

Table. 4. Expert Validation Results

\begin{tabular}{clccc}
\hline No. & Expert Validator & $\%$ & Validity & Appropriateness \\
\hline $\mathbf{1}$ & Sociology Material & 93,75 & Very valid & Very decent \\
& Historical Materi Sejarah & 93,75 & Very valid & Very decent \\
& Geography Material & 87,50 & Valid & Worthy \\
& Economic material & 90,62 & Valid & Worthy
\end{tabular}




\begin{tabular}{|c|c|c|c|c|}
\hline & Material Integration & 91,67 & Very valid & Very decent \\
\hline 2 & Indonesian & 91,67 & Very valid & Very decent \\
\hline \multirow[t]{2}{*}{3} & Textbooks & 91,32 & Very valid & Very decent \\
\hline & Overall average & 91,32 & Very valid & Very decent \\
\hline
\end{tabular}

Based on the table above, it shows that the average score of expert validator as a whole is $91.32 \%$ or categorized as very valid, so it can be stated that character-based social studies learning with connected models are very feasible to be used by lecturers and students of Unimed FIS, especially in subjects Integrated social studies learning. The validation results show that IPS textbooks are very valid and very feasible to use, so the next step is field trials. Field trials were carried out using social studies textbooks at the majors/study programs at FIS Unimed and were examined by 15 students each. The results of the field trials are presented in the following Table 5 below.

Table. 5. Field Trial Results

\begin{tabular}{clccc}
\hline No. & Indicator Character & protest & Postes & Enhancement \\
\hline 1 & Caring & 42,22 & 95,56 & 53,34 \\
2 & Self-discipline & 31,11 & 80,00 & 48,89 \\
3 & Responsibility & 42,22 & 86,67 & 44,45 \\
4 & Honestly & 31,11 & 84,44 & 53,33 \\
5 & Citizenship & 53,33 & 95,56 & 42,23 \\
& Average & 39,99 & 88,45 & 48,46 \\
\hline
\end{tabular}

Based on the table above, it shows that the overall average score on: (1) pretest is 39.99; (2) post-test of 88, 45; and (3) an increase of 48.46. The data also shows that there is an increase in every indicator of student character, namely: (1) caring by 53, 34; (2) selfdiscipline of 48, 89; (3) responsibility of 44.45; (4) honestly by 55.33; and (5) citizenship of 42,23 . The results of field trials prove the application of social studies textbooks with connected models can improve all indicators of student character.

Product effectiveness is the final stage in this research. The effectiveness of the product is done by analyzing the results of expert validation regarding the validity and feasibility of the product, as well as the results of field trials regarding improving student character. The results of the effectiveness of the product serve as a benchmark for the success of researchers in answering questions in this study. Based on the results of the study, it was found: the average rating of the expert validator was $91.32 \%$ or categorized as very valid. Therefore, characterbased social studies textbooks with connected models are very suitable for use by Unimed FIS students. The results of this study also showed that the character of Unimed FIS students increased after using social studies textbooks developed in this study.

\section{Conclusion}

Character-based social studies learning with connected models is very feasible to be used by lecturers and students at FIS Unimed, especially in Integrated Social Studies learning subjects the results of this study also show, the application of social studies textbooks with connected models can improve all student indicators including caring, self- discipline, responsibility, honesty, and citizenship.

Based on the results of the above research, researchers provide recommendations to lecturers supporting social studies subjects to design social studies learning that can integrate social science content closely related to one concept to another (connected). This needs to be 
done to achieve the ability of students to solve social problems employing connected, integrated, and transdisciplinary.

\section{References}

[1] T. Lickona, Educating for Character: How Our Schools Can Teach Respect and Responsibility. New York: Bantan Books, 1991.

[2] A. I. Muazza, T. Simanjuntak, "Pengembangan Bahan Ajar IPS Terpadu Berkarakter SMP Kelas VII Semester I," Jurnal Tekno Pedagogi, vol. 3, no. 2, pp. 25-34, 2013.

[3] P. I Sulistyo, Darsono., "Model connected dalam Pembelajaran IPS Berkarakter," FKIP Universitas Lampung, 2012.

[4] D. Setiawan, "Validator's View in the Implementation of Curriculum Oriented on yhr Indonesia National Qualification Framework (KKNI) Social Science Fsculty," IOSR Journal, vol. 22, no. 12, 2017.

[5] Pargito, IPS Terpadu. Lampung: PPs Pendidikan IPS Universitas Lampung, 2010.

[6] National Council for The Social Studies, Essential of the Social Studies. Washington, D.C.: NCSS, 1981.

[7] Prabowo, "Pembelajaran Fisika dengan Pendekatan Terpadu dalam Menghadapi Perkembangan IPTEK Milenium III," Semarang, 2000.

[8] Tim Pengembang PDSG, Pembelajaran Terpadu D-II dan S-II Pendidikan Dasar. Jakarta: Dirjen Dikti, 1997.

[9] AM Sardiman, "Pengembangan Kurikulum Pendidikan IPS di Indonesia: Sebuah Alternatif," Semarang, 2006.

[10] R. Fogarty, How to Integratedthe Curricula. Ilinois: Skylight Publishing, Inc, 1991.

[11] Nana Syaodih Sukmadinata, Metode Penelitian Pendidikan. Bandung: Rosdakarya, 2007.

[12] Sugiyono, Metode Penelitian Kuantitatif Kualitatif dan $R \& D$. Bandung: Alfabeta, 2008.

[13] N. Sudjana, Penilaian Hasil Proses Belajar Mengajar. Bandung: Remaja Rosdakarya, 2007. 